\title{
Unravelling the Roles of Nitrogen Nutrition in Plant Disease Defences
}

\author{
Yuming Sun ${ }^{1,2}$, Min Wang ${ }^{1, *}$, Luis Alejandro Jose Mur ${ }^{3}\left(\mathbb{D}\right.$, Qirong Shen ${ }^{1}$ and Shiwei Guo ${ }^{1}$ \\ 1 Jiangsu Provincial Key Lab of Solid Organic Waste Utilization, Jiangsu Collaborative Innovation Center of \\ Solid Organic Wastes, Educational Ministry Engineering Center of Resource-saving fertilizers, Nanjing \\ Agricultural University, Nanjing 210095, China; sunyumingagw@163.com (Y.S.); \\ shenqirong@njau.edu.cn (Q.S.); sguo@njau.edu.cn (S.G.) \\ 2 Jiangsu Key Laboratory for the Research and Utilization of Plant Resources, Institute of Botany, Jiangsu \\ Province and Chinese Academy of Sciences, Nanjing 210014, China \\ 3 Institute of Biological, Environmental and Rural Sciences, Aberystwyth University, Aberystwyth SY23 3DA, \\ UK; lum@aber.ac.uk \\ * Correspondence: minwang@njau.edu.cn; Tel.: +86-25-8439-5212
}

Received: 10 December 2019; Accepted: 13 January 2020; Published: 16 January 2020

\begin{abstract}
Nitrogen $(\mathrm{N})$ is one of the most important elements that has a central impact on plant growth and yield. $\mathrm{N}$ is also widely involved in plant stress responses, but its roles in host-pathogen interactions are complex as each affects the other. In this review, we summarize the relationship between $\mathrm{N}$ nutrition and plant disease and stress its importance for both host and pathogen. From the perspective of the pathogen, we describe how $\mathrm{N}$ can affect the pathogen's infection strategy, whether necrotrophic or biotrophic. $\mathrm{N}$ can influence the deployment of virulence factors such as type III secretion systems in bacterial pathogen or contribute nutrients such as gamma-aminobutyric acid to the invader. Considering the host, the association between $\mathrm{N}$ nutrition and plant defence is considered in terms of physical, biochemical and genetic mechanisms. Generally, N has negative effects on physical defences and the production of anti-microbial phytoalexins but positive effects on defence-related enzymes and proteins to affect local defence as well as systemic resistance. $\mathrm{N}$ nutrition can also influence defence via amino acid metabolism and hormone production to affect downstream defence-related gene expression via transcriptional regulation and nitric oxide (NO) production, which represents a direct link with $\mathrm{N}$. Although the critical role of N nutrition in plant defences is stressed in this review, further work is urgently needed to provide a comprehensive understanding of how opposing virulence and defence mechanisms are influenced by interacting networks.
\end{abstract}

Keywords: nitrogen; plant disease; physical; biochemical; molecular; disease defence

\section{Introduction}

Throughout its life, a plant is often exposed to a wide range of soil-borne or air-borne pathogens that represent a threat to plant normal growth and seed production. Therefore, pathogens can have considerable impacts on agricultural productivity and with major economic consequences. With millions of years of evolution, plants have formed multi-layered defence systems to perceive and resist invasion by these various types of pathogenic microorganisms, which include bacteria, fungi, nematodes or viruses. Simply classified, the plant defence systems can be divided into constitutive and induced modes [1]. Constitutive defence tends to involve only the outmost layer of plant tissues and, therefore, tends to be the first defensive line to be exposed to the invading pathogens. Typically, this form of defence consists of physical barriers and pre-formed chemical compounds (Figure 1) [2,3]. The strength of the physical barrier directly determines the number of pathogens entering the plant so that 
changes in the cuticle permeability, cell wall thickness and the degree of lignification critically affect plant resistance to pathogen infection $[4,5]$. The associated chemical defences consist primarily of secondary metabolites that inhibit microbial growth and further invasion. Antimicrobial phytochemicals may also serve as defence-related signallings to augment their importance on plant immunity $[6,7]$.

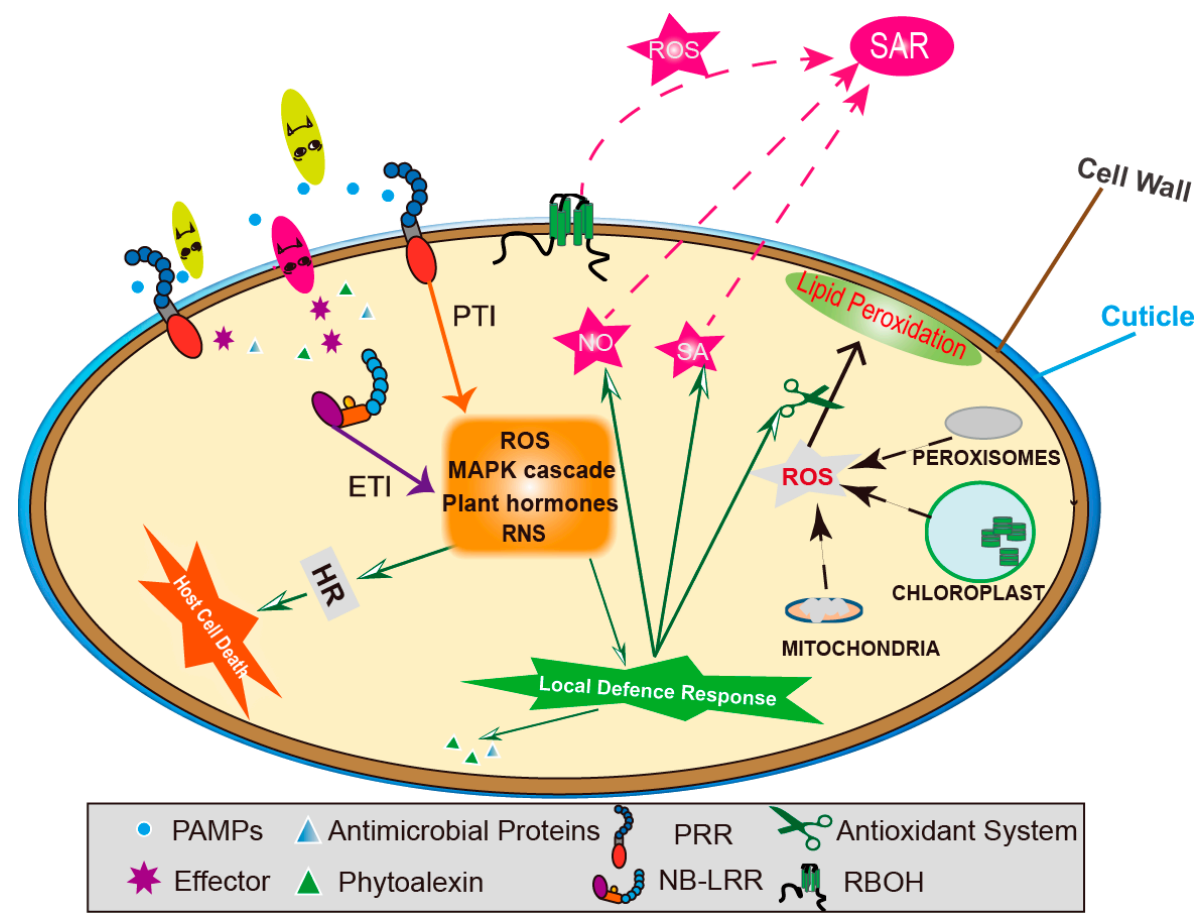

Figure 1. A model of plant immunity to pathogenic microorganism infection. The invading pathogenic microorganisms are first subject to plant physical (the outermost cuticle and epicuticular wax together with the lignified cell wall) and chemical barriers (phytoalexin and antimicrobial proteins). Simultaneously, the pattern recognition receptors (PRRs) located at the membrane recognize pathogen-associated molecular patterns (PAMPs) to induce PAMP-triggered immunity (PTI), while the nucleotide-binding leucine-rich repeat (NB-LRR) proteins recognize effectors delivered by pathogens and induce effector-triggered immunity (ETI). The PTI and ETI activate downstream defence including the local defence response and host cell death, mediated by a series of signal or regulatory factors (such as reactive oxygen species (ROS), reactive nitrogen species (RNS), mitogen-activated protein kinase (MAPK) cascades and hormones). The antioxidant systems are also stimulated to maintain intracellular redox balance. Furthermore, signals including nitric oxide (NO), salicylic acid (SA) and NADPH oxidase (RBOH)-generated ROS act to induce systemic acquired resistance (SAR) in uninfected tissues.

Plants can also recognize pathogen (or microbial)-associated molecular patterns (PAMPs/MAMPs) or damage-associated molecular patterns (DAMPs) through pattern recognition receptors (PRRs) to induce PAMP-triggered immunity (PTI) [8,9]. However, pathogens can evolve effectors to suppress PTI, leading to effector-triggered susceptibility (ETS). If effectors are recognized by Resistance $(R)$ gene encoded nucleotide-binding leucine-rich repeat (NB-LRR) proteins, plants can deploy effector-triggered immunity (ETI) [10]. ETI is a more prolonged and robust response than PTI but can only be deployed against specific pathogen infections [11]. Both PTI and ETI act through integrated signalling networks to defend against pathogens in a more specific manner with varying responses depending on the interacting pathogen. The outcomes of PTI/ETI can include the expression of differing defence genes, the formation of phytoalexins and the development of a hypersensitive response (HR) at the infection site $[9,12]$. Such defence responses can be reiterated throughout the plant to confer systemic acquired resistance (SAR). These induced defences can also be elicited by beneficial microbes, herbivores, chemical inducer or abiotic stress [13]. The pathogen-induced SAR occurs in the distal tissue to enhance the broad-spectrum resistance against secondary related or unrelated pathogenic challenges. Such 
resistance is achieved via the action of signalling compounds generated at the site of primary infection, such as reactive oxygen species (ROS), nitric oxide (NO) and salicylic acid (SA) (Figure 1) [14,15].

The interaction between plants and pathogenic microorganisms is therefore complex but can be influenced by multiple environmental factors such as temperature, humidity, light and nutrients. In this context, nitrogen $(\mathrm{N})$ is particularly important as an essential macroelement for plant normal growth and development, which accounts for $\sim 1.5 \%$ to $2 \%$ of plant dry matter and $\sim 16 \%$ of total plant proteins [16]. $\mathrm{N}$ assimilation is related to key physiological or metabolic processes such as photosynthesis, photorespiration, respiration, amino acid synthesis and the tricarboxylic acid (TCA) cycle $[17,18]$. Given its centrality, it is unsurprising that a plant's N status can influence plant resistance to varied abiotic and biotic stresses. For instance, numerous studies have shown that $\mathrm{N}$ supply can alter plant resilience to abiotic stresses possibly through effect-associated plant growth patterns and $\mathrm{N}$-mediated signalling transduction [19]. In the context of plant disease, $\mathrm{N}$ availability can limit pathogen growth and affect the elicitation and deployment of plant defences. Additionally, the supply of different forms of $\mathrm{N}$ (ammonium $\left[\mathrm{NH}_{4}{ }^{+}\right]$vs. nitrate $\left[\mathrm{NO}_{3}{ }^{-}\right]$) appears to have different effects on plant disease resistance, at least in part through the use of different assimilation and metabolism pathways $[20,21]$. However, such studies are primarily observational and descriptive, and the underlying defence mechanisms mediated by $\mathrm{N}$ are still not fully understood. Further, the impact on $\mathrm{N}$ of both of the interacting partners, host and pathogen, needs to be more clearly defined. In this review, we comprehensively consider the relationship between $\mathrm{N}$ nutrition and plant disease incidence as suggested by its effects on host and pathogen from physical, biochemical and molecular perspectives.

\section{N Nutrition as It Impacts on the Pathogen}

There are many instances where $\mathrm{N}$ fertilization can increase plant disease incidence, for example, with downy mildew, powdery mildew, leaf rust, stem rot and rice blast diseases [22-25]. Equally, the opposite effects have been reported for take-all, grey mould and leaf spot disease [26-29] (Table 1). These different outcomes cannot be associated with a given host (e.g., wheat) or different infection strategy, whether necrotrophic or (hemi)biotrophic or if a foliar or root-infecting pathogen. Necrotrophic pathogens cause host cell death through the production of toxins or enzymes, whilst biotrophs maintain host cell viability for an extended period. With time, biotrophs can switch to a necrotrophic mode of pathogenesis and are hence designated hemibiotrophs. Previous studies indicated that $\mathrm{N}$ fertilization could mostly increase plant disease incidence with biotrophic pathogen infection, while the opposite result occurs when challenged with necrotrophs such as Alternaria and Fusarium [30,31]. Whilst this could indicate that the requirement for viable host cells makes biotrophs sensitive to host $\mathrm{N}$ status, in Arabidopsis resistance to necrotrophic pathogens, Erwinia amylovora and Botrytis cinerea are inversely regulated by $\mathrm{N}$ nutrition [31,32]. Instead, it seems likely to reflect the interplay of specific elicitation events between pathogen and host. These elicitation events need to be defined and they could be used to improve crop yield without compromising resistance to disease.

Table 1. Number of published papers reporting the effects of nitrogen nutrition on plant disease incidence.

\begin{tabular}{cccc}
\hline \multirow{2}{*}{ Disease Incidence } & \multicolumn{3}{c}{ Effect of Nitrogen in the Form of } \\
\cline { 2 - 4 } & Unspecified N & $\mathbf{N H}_{\mathbf{4}}{ }^{+}$ & $\mathbf{N O}^{-}{ }^{-}$ \\
\hline Cases & 73 & 19 & 22 \\
Increase in disease & 40 & 9 & 13 \\
Decrease in disease & 25 & 9 & 8 \\
No effect or variable & 8 & 1 & 1 \\
\hline
\end{tabular}

The data were collected from 132 published papers that related to nitrogen nutrition and plant disease ranging from 1944 to 2019. 
In addition, factors such as plant growth stages, cultivars and planting years would also induce conflicting effects on the correlation between $\mathrm{N}$ nutrition and the effectiveness of pathogen infection $[33,34]$. All these discrete influences most likely reflect either the requirement of pathogenic proliferation or virulence on the availably of $\mathrm{N}[20,30]$. As an additional complication, the form of $\mathrm{N}$ fertilization can change plant disease severity. Thus, $\mathrm{NH}_{4}{ }^{+}$nutrition significantly increased plant resistance to take-all disease in wheat [35], summer patch in bluegrass [36] and black root rot in strawberry [37], while $\mathrm{NO}_{3}{ }^{-}$nutrition induced plant resistance to Fusarium infection [38,39].

From the perspective of pathogens, $\mathrm{N}$-promoted plant growth provides increased succulent tissues, apoplastic amino acid concentrations and improved plant canopy structure, which would all favour the growth of pathogenic spores $[40,41]$. On infection, pathogens require a wide range of $\mathrm{N}$ sources, including $\mathrm{NH}_{4}{ }^{+}$and $\mathrm{NO}_{3}{ }^{-}$as well as amino acids. Studies have shown that biotrophic pathogen infection induced amino acid accumulation at the infection site, among which gamma-aminobutyric acid (GABA) is an important $\mathrm{N}$ source for the development of Cladosporium fulvum [42], Stagonospora nodorum and Fusarium graminearum [43]. Additionally, different forms of $\mathrm{N}$ nutrition affect the development of pathogenic microorganisms. Unlike $\mathrm{NO}_{3}{ }^{-}$feeding, $\mathrm{NH}_{4}{ }^{+}$can inhibit the proliferation of Fusarium oxysporum [44,45], Vetticillium dahlia [46] and Elsinochrome [47], while the opposite events were also reported in Fusarium oxysporum f. sp. citri [38], aflatoxin [48] and various root rot diseases [49].

Direct $\mathrm{N}$ impacts on pathogen virulence have been noted with effector delivery. Thus, $\mathrm{N}$ starvation stimulates pathogen effector genes, such as the hrp (hypersensitive response and pathogenicity), Avr (avirulence) and hydrophobin MPG1 genes in Magnaporthe oryzae [50,51]. In an extensive transcriptomic assessment of the impact of $\mathrm{N}$ limitation on Pseudomonas syringae pv. syringae B728a, it was suggested that virulence-associated features such as swarming motility, type III secretion and metabolic pathways involved in GABA and polyketide metabolism were prominent [21]. Such studies indicate the importance of $\mathrm{N}$-starvation in initiating pathogenesis. Equally, the opposite effects have been documented for effectors from Magnaporthe oryzae [22] and Cladosporium fulvum [52]. However, the changes of pathogens alone cannot explain the discrete relationship between $\mathrm{N}$ nutrition and plant disease incidence. It becomes more complex when understanding it from the perspective of plants, as the effect of $\mathrm{N}$ nutrition on plant defence mechanisms.

\section{N Nutrition as It Impacts on Host Defence}

\subsection{Physical Defence Mechanisms}

Plant $\mathrm{N}$ availability modulates cellular structure and composition via its effects on plant in vivo primary and secondary metabolism. These will affect plant disease defences by affecting the thickness of the plant's physical barrier. Generally, increased N input will promote plant growth but at the price of less formation of lignin and waxy cuticle. The negative correlation between plant $\mathrm{N}$ status and surface wax density was demonstrated in both Pinus Palustris and Norway spruce seedlings $[53,54]$. Further, use of histochemical staining, biochemical assays and gene expression patterns have consistently demonstrated the negative impact of increased $\mathrm{N}$ availability on the degree of lignification of woody plant tissues [55,56]. Delayed lignin deposition on the xylem cell wall was observed when plants are exposed to excess $\mathrm{N}$ input [56]. In another study, high $\mathrm{N}$ fertilization resulted in a reduction in the thickness of the secondary cell wall as well as major biopolymer components (cellulose and lignin) in two japonica rice cultivars [57]. Interestingly, agronomically reducing the $\mathrm{N}$ fertilization rate can effectively increase plant lodging resistance, which is associated with changes in stem lignification and secondary cell wall synthesis and also emphasizes the negative correlation between $\mathrm{N}$ availability and plant epidermal hardness [58,59].

If these structures are compromised, plants will become conducive to penetration by pathogenic microorganisms as well as herbivorous insects [60]. This could partially explain the differences in plant susceptibility to various diseases influenced by $\mathrm{N}$ nutrition that are associated with physical resistance. Negative effects of $\mathrm{N}$ fertilization on epidermal cuticle thickness as well as disease susceptibility 
have been seen in the leaf of tomato [61] and fruit of peach [62]. The degree of plant epidermal lignification can effectively prevent the penetration of pathogens, thereby reducing the incidence of disease [4]. Furthermore, as a key enzyme in lignin biosynthesis, cinnamyl alcohol dehydrogenase is negatively regulated by $\mathrm{N}$ fertilization, and its inhibition makes Arabidopsis more susceptible to Pseudomonas syringae pv. tomato [63]. However, Nobuaki [64] reported the contradictory impacts of N fertilization on leaf cell wall thickness and blast disease in rice plants, although this could represent a requirement for particular cuticular characteristics to allow host penetration by Magnaporthe grisea [65]. In addition, different forms of $\mathrm{N}$ nutrition can also influence the strength of the plant's physical defence. For instance, compared with $\mathrm{NO}_{3}{ }^{-}, \mathrm{NH}_{4}{ }^{+}$-based $\mathrm{N}$ nutrition significantly increased the amount of epicuticular wax of kohlrabi leaves [66]. Wang et al. [67] showed that $\mathrm{NH}_{4}{ }^{+}$increases the activities of four peroxidase (POD) isoenzymes involved in lignin synthesis.

To further explain the regulation mechanism of $\mathrm{N}$ nutrition on physical defence compounds, the growth-defence balance hypothesis $(\mathrm{GDBH})$ or carbon (C)-nutrient balance hypothesis $(\mathrm{CNBH})$ could be informative. These emphasize either the balance between plant growth and defence or the importance of $\mathrm{C} / \mathrm{N}$ ratio in $\mathrm{C}$-based secondary metabolism $[68,69]$. These two theories are not mutually exclusive and would explain changes in C-base secondary metabolites such as lignin and cellulose. Thus, increased $\mathrm{N}$ supply promotes primary metabolism to drive growth, which inevitably inhibited C-base secondary metabolism [70]. This in turn would support the hypothesis of a negative relationship between $\mathrm{N}$ nutrition and physical defence strength.

\subsection{Plant Biochemical Defence Mechanism}

Biochemical defences are mainly achieved through multiple defence-related enzymes acting to affect primary or secondary metabolites. $\mathrm{N}$ mediated biochemical defences are associated with (1) plant metabolites including phytoalexins, antimicrobial proteins, amino acids and organic acids and (2) defence-related enzymes [71-73].

\subsubsection{Plant Metabolites and Biochemical Defence}

The class of metabolites known as phytoalexins are important components against pathogens. Phytoalexins are non-specific antimicrobial metabolites of low molecular weight that can effectively inhibit mycelial growth and spore germination. A reduction of phytoalexins contents increases plant susceptibility to disease [74]. Phytoalexins exhibit enormous chemical diversity, with the most studied being the flavonoids in legume (e.g., isoflavones, coumarin and chlorogenic acid), terpenoids in Solanaceae and Convolvulaceae (e.g., gossypol, kauralexins and zealexins), stilbenes (e.g., resveratrol) and indoles (e.g., camalexin, brassinin, glucosinolates and brassilexin) [75-77].

Since most of the phytoalexins are C-based secondary metabolites, their contents are also likely to be negatively regulated by $\mathrm{N}$ availability as predicted by the CNBH or GDBH (Table 2). For example, tests in soybean, Salix polaris and subarctic tundra heath vegetation showed a negative regulation of $\mathrm{N}$ on plant defensive compounds such as coumestrol, total phenols or condensed tannins [78-80]. In another study, fungistatic phenolic compounds such as (-)-epicatechin and piceatannol in beech roots and 4-hydroxyacetophenone and piceatannol in Norway spruce root also decreased with increasing $\mathrm{N}$ fertilization; however, there was an increase in protocatechuic acid content [81]. These findings suggest that $\mathrm{N}$ addition generally reduces the amount of defensive compounds and affects plant disease resistance. Thus, $\mathrm{N}$ addition compromised rice resistance to sheath rot (Sarocladium oryzae) [82], grapevines to powdery mildew (Uncinula necator) [83], Medicago truncatula to Aphanomyces euteiches [84], potato to Phytophthora infestans [85] and apple tree to Venturia inaequalis [86]. However, N forms also affect the synthesis of C-based secondary metabolites. For instance, $\mathrm{Wu}$ et al. [87] found that $\mathrm{NO}_{3}{ }^{-}$nutrition increased total phenol and flavonoids in Echinacea angustifolia and total flavonoids in Hypericum perforatum [88] and in Leafy Brassica [89]. Similarly, higher $\mathrm{NO}_{3}{ }^{-} / \mathrm{NH}_{4}{ }^{+}$ratios in Murashige and Skoog medium increased the production of C-based secondary metabolites, including ginseng saponin, artemisinin and periplocin [90-92]. The promoting effect of $\mathrm{NO}_{3}{ }^{-}$on secondary metabolites, 
including various phytoalexins, may be linked to defence simulated by nitrate reductase ( $\mathrm{Nr})$-derived NO signals (considered below).

Table 2. Defence-related enzymes or compounds regulated by nitrogen during plant disease resistance.

\begin{tabular}{|c|c|c|c|c|}
\hline Host & Disease & Pathogen & $\begin{array}{c}\text { Defence-Related } \\
\text { Enzymes/Compounds }\end{array}$ & Reference \\
\hline Apple tree & Scab disease & $\begin{array}{l}\text { Venturia } \\
\text { inaequalis }\end{array}$ & Procyanidins, Flavonols & [86] \\
\hline Grapevines & $\begin{array}{l}\text { Powdery } \\
\text { mildew }\end{array}$ & Uncinula necator & Flavonol glycosides, Cinnamic acid & [83] \\
\hline $\begin{array}{l}\text { Medicago } \\
\text { truncatula }\end{array}$ & Root rot & $\begin{array}{l}\text { Aphanomyces } \\
\text { euteiches }\end{array}$ & $\begin{array}{c}\text { Soluble phenolics, Phenylalanine } \\
\text { ammonia lyase }\end{array}$ & [84] \\
\hline Potato & Early blight & Alternaria solani & $\begin{array}{l}\text { Chlorogenic acid, Flavonols, } \\
\text { Neochlorogenic acid }\end{array}$ & [85] \\
\hline \multirow{4}{*}{ Rice } & Late blight & $\begin{array}{l}\text { Phytophthora } \\
\text { infestans }\end{array}$ & $\begin{array}{c}\text { Phenylalanine ammonia lyase, } \\
\text { Polyphenol oxidase, chitinase, } \\
\text { Flavonols }\end{array}$ & [93] \\
\hline & Leaf necrosis & potato virus $Y$ & Phenylalanine ammonia lyase & [94] \\
\hline & \multirow[t]{2}{*}{ Rice blast } & $\begin{array}{l}\text { Magnaporthe } \\
\text { grisea }\end{array}$ & Sulfur-rich thaumatin-like protein & [95] \\
\hline & & $\begin{array}{l}\text { Magnaporthe } \\
\text { oryzae }\end{array}$ & $\begin{array}{c}\text { Phenylalanine ammonia lyase, } \\
\text { Superoxide dismutase, Glucanases, } \\
\text { Chitosanase, Phenylalanine ammonia } \\
\text { lyase, }\end{array}$ & {$[24,96]$} \\
\hline \multirow{3}{*}{ Tomato } & Sheath rot & $\begin{array}{l}\text { Sarocladium } \\
\text { oryzae }\end{array}$ & Phenols & [82] \\
\hline & Bacterial speck & $\begin{array}{l}\text { Pseudomonas } \\
\text { syringae }\end{array}$ & Superoxide dismutase & [97] \\
\hline & Fusarium wilt & $\begin{array}{l}\text { Fusarium } \\
\text { oxysporum }\end{array}$ & Phenols, peroxidase & [98] \\
\hline
\end{tabular}

Most of the antimicrobial proteins are $\mathrm{N}$-based compounds and their responses to $\mathrm{N}$ availability are different from those of phenolic-defensive compounds (Table 2). Pathogenesis-related (PR) proteins, chitinase and $\beta$-glucanase can degrade the glycoside peptide of bacterial cell wall and chitin or dextran of the fungal cell wall to counter pathogen infection [99]. Thus, the inhibition or induction of PR proteins will result in either a decreased or enhanced plant resistance [100]. The activity of chitinase (PR3), as well as $\beta$-1,3-glucanase (PR-2 protein) and chitosanase, increased with the increased $\mathrm{N}$ fertilization rate $[1,93]$, which correlated with enhanced plant disease resistance. Correspondingly, significant down-regulation of genes encoding class IV chitinase (3.7-fold) and class III chitinase (10.2-fold) was observed in rice when exposed to low N stress [101]. Another study documented the increased expression of PR4 with increased N [102]. These findings indicate a positive effect of $\mathrm{N}$ nutrition on the expression of PR proteins which could be linked to disease resistance. However, no significant variation in chitinase activities was observed in Arabidopsis thaliana exposed to different $\mathrm{N}$ rates [103]. Another important class of antifungal proteins, protease inhibitors, also play a role in plant immunity [104]. These exhibit positive [105], negative [106] and non-significant [107] effects following $\mathrm{N}$ manipulation. Further, any positive effects of $\mathrm{N}$ on PR gene expression would appear to be countered by wider negative impacts on defence in particular interactions. A proteomic study on rice-Magnaporthe grisea showed that the expression of a sulfur-rich thaumatin-like protein (PR-5) (an antimicrobial protein) was enhanced following challenge with blast fungus incubation under high $\mathrm{N}$ feeding [95], although high $\mathrm{N}$ made rice susceptible to blast disease. Thus, the $\mathrm{N}$ mediated changes in PR proteins are not necessarily consistent with disease resistance, which arises from multiple factors.

Primary $\mathrm{C}-\mathrm{N}$ metabolites, mainly amino acids and organic acids, link $\mathrm{N}$ nutrition and disease due to the need of the pathogen to derive nutrients from the host [108]. Amino acid and organic acid metabolism can be markedly affected by either the rate of $\mathrm{N}$ application or its forms. $\mathrm{N}$ input 
generally enhances amino acid content but restricts organic acid metabolism [109]. $\mathrm{NH}_{4}{ }^{+}$nutrition increased amino acid content of cucumber plants when compared with $\mathrm{NO}_{3}{ }^{-}$nutrition, while the opposite results were exhibited for organic acids [71,97].

Amino acid metabolism is disrupted during plant disease, affecting the overall accumulation patterns or those of individual amino acids. This is particularly relevant as recent functional studies in Arabidopsis indicate that amino acid metabolism contributes more to plant disease defence than phytoalexins [72,110]. Furthermore, metabolically, amino acids are in fact precursors of many defence-related phytoalexins. For example, glucosinolate is a major phytoalexin in Brassica plants, and different categories of glucosinolates are derived from amino acids like alanine, phenylalanine and tryptophan [111]. Equally, high $\mathrm{N}$-induced glucosinolate accumulation has also been reported in Brassica plants [112]. The acylation of amino acids can also affect plant resistance to microbial pathogens and insects. $\mathrm{N}$-acetylornithine derived from arginine, proline and glutamate catabolic pathways increases the susceptibility of Arabidopsis to Pseudomonas syringae infection but protects plants from feeding by aphid and herbivores [72,113].

Predictably, the direct manipulation of amino acids can increase disease resistance. Exogenous treatment of proline could enhance the expression of $P R$ as well as HR-mediated programmed cell death (PCD), with similar results elucidated in homoserine- or threonine-mediated plant immunity to oomycete pathogens [72,114]. Deletion or overexpression of asparagine synthetase 1 (CaAS1) respectively decreased or enhanced Arabidopsis thaliana defence to Pseudomonas syringae pv. tomato DC3000 and Hyaloperonospora arabidopsidis [115], whilst overexpression of aspartate aminotransferase resulted in increased plant disease incidence in Arabidopsis thaliana challenged with Botrytis cinerea [116]. Liu et al. [117] also demonstrated that the knockout of amino acid transporters such as LYSINE HISTIDINE TRANSPORTER1 (LHT1) would reduce the contents of glutamine, alanine, and proline but promote callose deposition and HR, thereby increasing Arabidopsis disease resistance. Beyond amino acids, wider amide metabolism appears to be affected by $\mathrm{N}$ supply. The oxidation of polyamines generates extracellular hydrogen peroxide $\left(\mathrm{H}_{2} \mathrm{O}_{2}\right)$ to trigger PCD or basal resistance and thus enhance plant disease resistance. A positive relationship between polyamine content and $\mathrm{N}$ supply levels has also been demonstrated $[118,119]$.

When it comes to the link between organic acids and plant immunity, the most well-characterized is the link between phenolic acids acting as phytoalexins, which are negatively controlled by $\mathrm{N}$ nutrition (as discussed above). However, other organic acids can also interfere with plant defence by affecting key metabolic processes. Thus, organic acids involved in the TCA cycle, including oxalic acid, malic acid, citrate acid, succinic acid and fumaric acid, can significantly affect plant resistance, as shown in the cucumber-Fusarium interaction when supplied with $\mathrm{NO}_{3}{ }^{-}[39,71]$. In addition, organic acids involved in photorespiration such as glycolic acid and glyoxylic acid also contribute to plant disease resistance. Inhibition of the glycolate oxidase, a component of the photorespiration cycle, compromised disease resistance and such processes are positively regulated by $\mathrm{N}$ nutrition, especially in the forms of $\mathrm{NO}_{3}{ }^{-}[120,121]$. Organic acids can also participate in plant defence as they include some signalling molecules. These include the important defence hormones SA and jasmonic acid (JA), which form regulatory networks with ethylene (ETH) and could be regulated by N nutrition (discuss below).

\subsubsection{Defence-Related Enzymes}

Activation of plant defence-related enzymes is another facet in fighting against pathogen invasion, and $\mathrm{N}$ is involved in the stimulation of these enzymes during plant-pathogen interactions (Table 2) [73, 96]. The phenylpropanoid pathway plays an important part in defence and the key regulatory enzyme in this pathway, phenylalanine ammonia_lyase (PAL), is involved in the synthesis of secondary antimicrobial compounds [122]. Generally, genes encoding general phenylpropanoid metabolism such as PAL, cinnamate-4-hydroxylase $(\mathrm{C} 4 \mathrm{H})$ and 4-coumarate: $\mathrm{CoA}$ ligase $(4 \mathrm{CL})$ are all up-regulated by $\mathrm{N}$ deficiency $[56,123]$, while decreased PAL activity has been seen with $\mathrm{N}$ fertilization $[60,124]$. However, discrete responses were reported when challenged with pathogens. For example, Thapa et al. [96] 
reported inhibited PAL activity as well as decreased plant resistance by $\mathrm{N}$ input in rice-Magnaporthe relations. A similar result was also observed in Medicago truncatula resistance to Aphanomyces euteiches [84]. In contrast, Jin et al. [93] demonstrated increased PAL activity and plant disease resistance by $\mathrm{N}$ fertilization, while Ballini et al. [24] reported the upregulation of genes encoding PAL and POD together with increased disease incidence due to high $\mathrm{N}$ supply. Furthermore, as a key enzyme converting phenolic compounds into antimicrobial hydrazines, polyphenol oxidase (PPO) also has a role in plant disease resistance; however, the effects of $\mathrm{N}$ fertilization had both positive [93] and negative [125] effects. These different responses suggest that the activation of these defence-related enzymes may not be the decisive strategy in $\mathrm{N}$-mediated plant defence or have different roles in differing interactions.

In addition, $\mathrm{N}$ nutrition also influences plant antioxidant systems, which play key roles in plant defence responses (Figure 1, Table 2). Antioxidant enzymes include superoxide dismutase (SOD), catalase (CAT), ascorbate peroxidase (APX), glutathione reductase (GR) and POD. These antioxidant enzymes reduce ROS under stresses to less toxic compounds [126]. $\mathrm{N}$ fertilization generally increases the activities of these enzymes, thereby enhancing plant antioxidant capacity and reducing cell membrane injury $[127,128]$. The $\mathrm{N}$ deficient-triggered $\mathrm{H}_{2} \mathrm{O}_{2}$ or superoxide anion accumulation in rice leaves [129], Matricaria chamomilla roots [130] and wheat peduncles [131] further support these observations. When considering the impact of different $\mathrm{N}$ sources, enhanced antioxidant enzyme activities and antioxidants (reduced glutathione, GSH and ascorbate, ASA) contents together with the decreased ROS levels were observed under $\mathrm{NO}_{3}{ }^{-}$feeding, especially after exposing to stress [132,133], which may be again associated with the NO-triggered defence responses [134]. However, antioxidant systems may be sensitive to $\mathrm{NH}_{4}{ }^{+}$feeding, which may again be associated with the oxidative damage due to "ammonium toxicity" $[67,135]$. Taking all of these points together, it seems that $\mathrm{N}$ can positively participate in plant biochemistry defence against biotic stresses via the antioxidant system.

\subsection{Plant MOLECULAR Defence Mechanism}

\subsubsection{N Metabolism Links Hormones and Nitric Oxide Impacts on Defence}

Plant hormones play critical roles in plant growth and development, among which SA, JA and ETH are essential regulators of plant defence responses [136]. SA signalling is mainly deployed when plants are challenged with biotrophic and hemibiotrophic pathogens, while JA and ET act synergistically against necrotrophic pathogens. A negative effect of $\mathrm{N}$ nutrition on SA accumulation has been reported in Arabidopsis leaves, but the response under disease was not tested [137]. The plant's in vivo $\mathrm{N}$ status can also influence the SA levels [137] or defence gene expression (e.g., PR2 and WRKY33) [138] via the action of RING-type ubiquitin E3 ligase. Interestingly, SA-mediated plant resistance is also linked to amino acids. For instance, SAR was induced in rice to Magnaporthe oryzae by amino acids, and the broad-spectrum local defence also linked to SA signalling [117]. The JA/ ET regulatory network involves the transcription factor ERF1, which can regulate the defence gene PDF1.2 [139]. Vega et al. [102] demonstrated that ERF1 was repressed under N-deficiency in the Solanum lycopersicum-Botrytis cinerea interaction. A similar repressive effect with $\mathrm{N}$-deficiency was also reported in the OPR3 gene, which increases tomato resistance to B. cinerea by affecting the JA biosynthesis pathway [140]. However, Farjad et al. [141] showed that high $\mathrm{N}$-environment-inhibited JA-related defences, resulted in higher bacterial pathogen cell numbers. Other plant hormones, such as abscisic acid (ABA), auxin, and cytokinin, are involved in plant defence and related to $\mathrm{N}$ nutrition. Perhaps most well-characterized is ABA, which can induce stomatal closure to prevent pathogenic bacterial infection but can also negatively affect plant immunity when acting as a signal molecule [142]. Notably, $\mathrm{N}$ deficiency can enhance $\mathrm{ABA}$ synthesis, while $\mathrm{NO}_{3}{ }^{-}$decreases $\mathrm{ABA}$ levels when compared with $\mathrm{NH}_{4}{ }^{+}[143,144]$. This may represent either nutritional stress or a role for $\mathrm{NO}$ and indicates the connection between $\mathrm{N}$ metabolism and ABA-regulated plant immunity. 
$\mathrm{N}$-mediated defence and homeostasis of phytohormone are also correlated by NO signals, and such interactions have been investigated by Mur et al. [145]. NO is a signal molecule that is closely related to $\mathrm{NO}_{3}{ }^{-}$nutrition due to the catalysis of $\mathrm{Nr}$, representing a direct link between $\mathrm{N}$ assimilation and NO generation. NO signalling is involved in many facets of plant immunity, such as the transcription regulation of the $P R$ gene and local HR-induced PCD [146,147]. NO-regulated PCD at the infection site can arise independently or synergistically with ROS, via the action of antioxidant enzymes or chemical generation of peroxynitrite (ONOO-) [148]. NO signal can also initiate the synthesis of plant phytoalexins or SA with direct roles in chemical defence or indirectly through localized and systemic resistance [149]. Most evidence suggests that the nitrite-dependent $\mathrm{Nr}$ pathway is the major source of NO during plant-pathogen interactions [118]. The importance of $\mathrm{Nr}$ in plant disease resistance, as well as the correlation with different forms of $\mathrm{N}$, has been highlighted in a number of studies. Thus, $\mathrm{NO}_{3}{ }^{-}$nutrition can enhance $\mathrm{NO}$ generation via $\mathrm{Nr}$ activity, while the $\mathrm{NO}$ signal is inhibited under $\mathrm{NH}_{4}{ }^{+}$condition [150]. Further, $\mathrm{NO}_{3}{ }^{-}$nutrition can regulate NO-mediated responses to pathogen infection, such as stomatal closure or the kinetics of the HR [128]. Thus, the Nr-deficient double mutant (nia1 nia2) of Arabidopsis thaliana exhibited an impaired HR against avirulent Pseudomonas [151]. Fumigation of nia1nia2 with NO restored the expression of defence-related genes and alleviated the disease symptoms [152]. A similar contribution by the nitrate transporter NRT2.1 has been reported with functions associated with SA and ROS changes [153]. The increased susceptibility of $n r t 2.1$ to Erwina amylovora linked plant defence to redox status and $\mathrm{N}$ metabolism, which was suggestive of $\mathrm{NO}$ effects. Furthermore, a lower $\left[\mathrm{NH}_{4}+\right] /\left[\mathrm{NO}_{3}{ }^{-}\right]$ratio can act in Arabidopsis ENHANCED DISEASE SUSCEPTIBILITY 1 (EDS1) to augment basal resistance through the action of NO [154]. A study from Gupta et al. [118] demonstrated that the HR-mediated local cell death in response to Pseudomonas was faster in $\mathrm{NO}_{3}{ }^{-}$fed than in $\mathrm{NH}_{4}{ }^{+}$fed tobacco plants, together with the increased plant resistance. Their more recent study associated the nitrite and NO increased hypersensitive response (HR) to the changes of amino acid and energy metabolism [155]. These results positively suggest that the NO signal can closely link $\mathrm{N}$ metabolism to plant resistance by manipulating downstream immune responses.

NO can actively participate in the hormone regulatory network, and the associations are demonstrated through the manipulation of haemoglobins ( $\mathrm{Hb}$; also known as phytoglobulins) oxidizing NO or a putative plant NO synthase (NOS) catalyzing L-arginine [156,157]. The NO signal can positively impact defence signalling by affecting the expression of the SA biosynthetic gene isochorismate synthase 1 (ICS1) or the JA biosynthesis genes LOX3, 12-oxophytodienoate reductase 1, 2, and 3 [145]. In NO-SA interactions, s-nitrosoglutathione can regulate SA synthesis or plant defence after S-nitrosylation of TGA1 or NPR1 [158]. NO can play either a positive or negative regulatory role in the ETH network. A positive correlation may involve the ETH biosynthetic genes 1-aminocyclopropane-l-carboxylic synthase $(A C S)$ or 1-aminocyclopropane-1-carboxylic acid oxidase (ACO). In contrast, a negative effect could involve suppression of methionine adenosyltransferase activity, which can reduce the provision of methyl groups required for ETH biosynthesis [145].

A transcriptional regulatory network identified by gene network analysis indicated that the hub transcription factor functioned in ETH and JA signalling, which was linked to N-enhanced resistance. These findings suggest the necessity of $\mathrm{N}$ in the downstream transcriptional regulation of ETH/JAmediated defence genes, and similar effects were also reported in HPL (encoding hydroperoxide lyase) in melon [159] and antioxidant-related genes in Populus [160]. When considering plant susceptibility caused by $\mathrm{N}$ nutrition, the interaction between Magnaporthe oryzae and rice has been used as a model. Huang et al. [22] revealed that high $\mathrm{N}$ fertilization not only promotes the expression of defence genes like $P R$ and those involved in the biosynthesis of the chemical defences but also induces several negative regulators of defence during rice-Magnaporthe oryzae relations. The study also showed the important role of the OsNAP gene in plant immunity, whose expression was eliminated by high N [22]. OsNAP has either a negative or positive effect on ABA or JA, which corresponds to the impacts on rice blast resistance [161,162]. A similar observation was noted in the Arabidopsis-Erwinia amylovora relations, with up-regulation of multiple resistance genes by $\mathrm{N}$-starvation and pathogen challenge, 
particularly PR1, WRYK33 and WRYK60, well-known positive regulators in plant defence [141]. This may reflect the preservation of plant defence programs under N-starvation stress, while the opposite conclusion cannot be drawn under high $\mathrm{N}$.

Different forms of $\mathrm{N}\left(\left[\mathrm{NH}_{4}{ }^{+}\right]\right.$vs. $\left.\left[\mathrm{NO}_{3}{ }^{-}\right]\right)$can also impact the plant molecular strategy against pathogens. Generally, $\mathrm{NH}_{4}{ }^{+}$mediated plant immunity was associated with the metabolism of amino acids, thereby affecting the development of pathogens or the expression of defence-related genes [163]. A recent study also highlighted the potential negative regulatory role of the ammonium transporter AMT 1.1 in plant disease resistance, which can be stimulated by $\mathrm{N}$ starvation [164]. However, in the context of $\mathrm{NO}_{3}{ }^{-}, \mathrm{NO}_{3}{ }^{-}$nutrition inevitably enhances the downstream immune response through the NO signal, thereby improving plant disease resistance.

\subsubsection{N Metabolism and SAR}

Unlike local defences, SAR has broad-spectrum resistance to all pathogenic microorganisms (e.g., fungi, oomycetes, viruses, and bacteria) and aims to support plant survival rather than death [15]. Therefore, the SAR event is also defined as defence priming [8]. SA is classically associated with SAR, but it has also been linked to the methylated derivative methyl salicylic acid (MeSA), azelaic acid (AzA) and phosphorylated sugar, glycerol-3-phosphate (G3P) [165]. For example, foliar application of SA can stimulate SAR and effectively prevent the development of Fusarium wilt [166]. However, SA is generally not considered to be the main long-range signal in establishing SAR. The establishment of SAR requires contributions from other signalling molecules, such as ROS and RNS, to further induce de novo biosynthesis of SA in systemic leaf tissue [167]. A direct connection between the level of plant in vivo $\mathrm{N}$ and the potency of SAR cannot be easily drawn from previous studies. However, it seems likely that $\mathrm{N}$ can mediate plant SAR by influencing the production of NO. The generation of a systemic NO signal was first observed in uninoculated tissues above the powdery mildew incubated tomato leaf [167]. A more detailed relationship was demonstrated in Arabidopsis-Pseudomonas syringae pv tomato interactions [168]. Studies demonstrated that NO confers SAR through the downstream regulation of ROS-AzA-G3P, which functioned parallel to SA-mediated events [168]. Recent studies have identified pipecolic acid (Pip), a lysine (Lys) catabolite, as an essential regulator of SAR [169]. Pathogen infection triggers the catabolism of Lys as well as the generation of Pip, which could be transported to the distal tissue and cause an amplification of SA dependent or independent SAR [170]. Pip-mediated SAR has been outlined in multiple plants and the action pattern has been elucidated. Crucially, exogenous application with Pip could reinstate SAR in AGD2-LIKE DEFENSE RESPONSE PROTEIN1 (ald1) mutant further confirmed the relationship between Pip and SAR [72,171]. The role of $\mathrm{N}$-influencing Lys-derived Pip has yet to be investigated but should feature in future studies.

\section{Conclusions and Perspective}

The relationship between $\mathrm{N}$ fertilization rates or forms and plant disease incidence is complicated, and the understanding of this relationship or the exploration of the underlying mechanisms is of great significance for agricultural practices. This review summarizes the $\mathrm{N}$ regulated effects in the pathogen and host. Its key take-home message must be that no generic model can describe the role of $\mathrm{N}$ in a given interaction. Pathogenic mechanisms and host defence responses are too variable. However, some broad themes can be identified, based on which individual exceptions in a particular pathosystem could be subsequently defined. These are described in the host in Figure 2. Firstly, N nutrition influences the strength of plant physical barriers with reduced wax layer thickness and lignin content to affect the penetration by pathogens. Secondly, N-induced biochemical defence represents a network of phytoalexins, antimicrobial proteins, defence-related enzymes, amino acid and organic acid metabolism, and endogenous hormones. Finally, at the molecular level, N nutrition can also manipulate defence-related gene expression via transcriptional regulation or signalling pathways mediated by hormones or amino acids. The NO signal is a crucial link to $\mathrm{N}$ forms and also plays an important positive role in both plant local defence and SAR. 


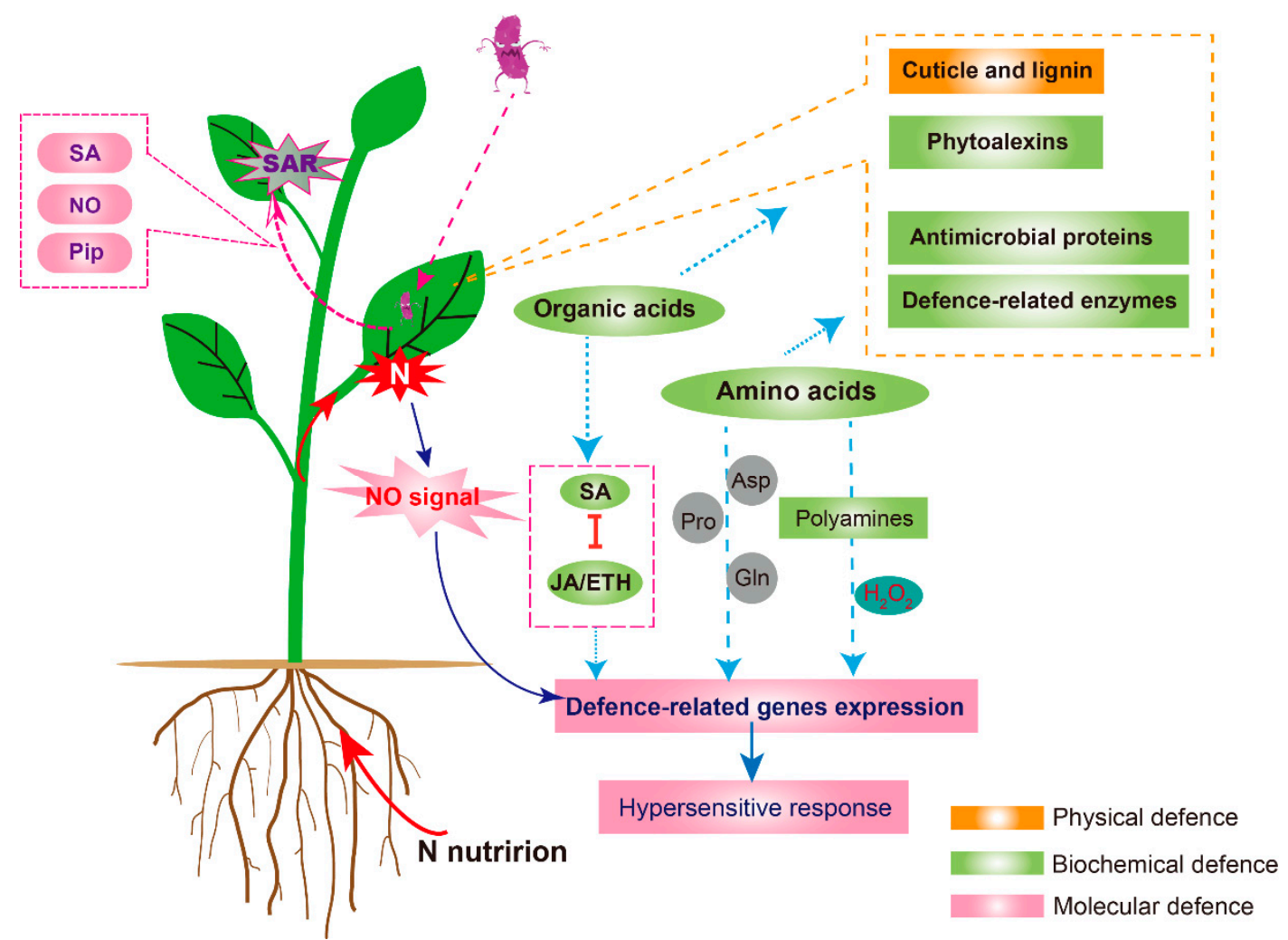

Figure 2. Proposed model for the interaction between nitrogen $(\mathrm{N})$ nutrition and plant physical, biochemistry and molecular defences. $\mathrm{N}$ nutrition is involved in the construction of the plant defence system, including the defined negative effects on physical defences and phytoalexins contents and the positive effects on antimicrobial proteins. $\mathrm{N}$ also mediates phytoalexin formation and downstream hypersensitive response via the amino acid metabolism. In addition, $\mathrm{N}$ nutrition can also regulate hormone (salicylic acid, SA; jasmonic acid, JA and ethylene, ETH) status and the subsequent defence genes expression patterns through organic acid metabolism or the function of nitric oxide (NO). NO signal is an important bridge between $\mathrm{N}$ nutrition and plant disease resistance, which is tightly linked to $\mathrm{N}$ forms. Notably, pipecolic acid (Pip) derived from lysine (Lys), NO signal, and SA can also mediate the distant systemic acquired resistance (SAR) together with reactive oxygen species (ROS), which is critical for plant survival when facing diseases.

Further studies should address the following: (1) the effects of $\mathrm{N}$ fertilization forms $\left(\left[\mathrm{NH}_{4}{ }^{+}\right]\right.$ vs. $\left.\left[\mathrm{NO}_{3}{ }^{-}\right]\right)$on plant thickness of wax layer and cuticle as well as the contents of phytoalexins and antimicrobial proteins when suffering diseases; (2) grafting and gene editing methods can be combined to study the mechanism of N-enhanced (or -compromised) SAR via NO signal or amino acid metabolism; (3) transcriptomics approaches should be broadly used to identify the regulatory pathway between $\mathrm{N}$ and HR at local site and SAR at distal site; (4) integrating $\mathrm{N}$ effect on the pathogen into the model possibly through approaches such as dual metabolomic approaches, where both host and pathogen are simultaneously assessed.

Author Contributions: Y.S. and M.W. contributed to the conception and design of the layout and prepared the manuscript; Y.S. and Q.S. contributed the table and figures; L.A.J.M. and S.G. added to the text as well as editing, proofreading and polishing the manuscript. All authors have read and agreed to the published version of the manuscript.

Funding: This work was supported by the National Key R\&D Program (2016YFD0200305), the Young Elite Scientists Sponsorship Program by CAST (2018QNRC001), the Innovative Research Team Development Plan of the Ministry of Education of China (IRT_17R56) and the Fundamental Research Funds for the Central Universities (KYT201802).

Conflicts of Interest: The authors declare no conflict of interest. 


\section{References}

1. Dietrich, R.; Ploss, K.; Heil, M. Constitutive and induced resistance to pathogens in Arabidopsis thaliana depends on nitrogen supply. Plant Cell Environ. 2004, 27, 896-906. [CrossRef]

2. Serrano, M.; Coluccia, F.; Torres, M.; L'Haridon, F.; Metraux, J.P. The cuticle and plant defense to pathogens. Front. Plant Sci. 2014, 5, 274. [CrossRef] [PubMed]

3. Grayer, R.J.; Kokubun, T. Plant-fungal interactions: The search for phytoalexins and other antifungal compounds from higher plants. Phytochemistry 2001, 56, 253-263. [CrossRef]

4. Kumar, A.; Yogendra, K.N.; Karre, S.; Kushalappa, A.C.; Dion, Y.; Choo, T.M. WAX INDUCER1 (HvWIN1) transcription factor regulates free fatty acid biosynthetic genes to reinforce cuticle to resist Fusarium head blight in barley spikelets. J. Exp. Bot. 2016, 67, 4127-4139. [CrossRef] [PubMed]

5. Sela, D.; Buxdorf, K.; Shi, J.X.; Feldmesser, E.; Schreiber, L.; Aharoni, A.; Levy, M. Overexpression of AtSHN1/WIN1 provokes unique defense responses. PLoS ONE 2013, 8, e70146. [CrossRef] [PubMed]

6. Bednarek, P.; Osbourn, A. Plant-microbe interactions: Chemical diversity in plant defense. Science 2009, 324, 746-748. [CrossRef]

7. Bednarek, P. Chemical warfare or modulators of defence responses - the function of secondary metabolites in plant immunity. Curr. Opin. Plant Biol. 2012, 15, 407-414. [CrossRef]

8. Conrath, U. Molecular aspects of defence priming. Trends Plant Sci. 2011, 16, 524-531. [CrossRef]

9. Miller, R.N.; Costa Alves, G.S.; Van Sluys, M.A. Plant immunity: Unravelling the complexity of plant responses to biotic stresses. Ann. Bot. 2017, 119, 681-687. [CrossRef]

10. Collier, S.M.; Moffett, P. NB-LRRs work a "bait and switch" on pathogens. Trends Plant Sci. 2009, 14, 521-529. [CrossRef]

11. Dodds, P.N.; Rathjen, J.P. Plant immunity: Towards an integrated view of plant-pathogen interactions. Nat. Rev. Genet. 2010, 11, 539-548. [CrossRef] [PubMed]

12. Tsuda, K.; Katagiri, F. Comparing signaling mechanisms engaged in pattern-triggered and effector-triggered immunity. Curr. Opin. Plant Biol. 2010, 13, 459-465. [CrossRef] [PubMed]

13. Mauch-Mani, B.; Baccelli, I.; Luna, E.; Flors, V. Defense priming: An adaptive part of induced resistance. Annu. Rev. Plant Biol. 2017, 68, 485-512. [CrossRef] [PubMed]

14. Mur, L.A.; Naylor, G.; Warner, S.A.; Sugars, J.M.; White, R.F.; Draper, J. Salicylic acid potentiates defence gene expression in tissue exhibiting acquired resistance to pathogen attack. Plant J. 1996, 9, 559-571. [CrossRef]

15. Fu, Z.Q.; Dong, X. Systemic Acquired Resistance: Turning Local Infection into Global Defense. Annu. Rev. Plant Biol. 2013, 64, 839-863. [CrossRef]

16. Scheible, W.-R.; Morcuende, R.; Czechowski, T.; Fritz, C.; Osuna, D.; Palacios-Rojas, N.; Schindelasch, D.; Thimm, O.; Udvardi, M.K.; Stitt, M. Genome-wide reprogramming of primary and secondary metabolism, protein synthesis, cellular growth processes, and the regulatory infrastructure of Arabidopsis in response to nitrogen. Plant Physiol. 2004, 136, 2483-2499. [CrossRef]

17. Makino, A. Photosynthesis, grain yield, and nitrogen utilization in rice and wheat. Plant Physiol. 2011, 155, 125-129. [CrossRef]

18. Foyer, C.H.; Noctor, G.; Hodges, M. Respiration and nitrogen assimilation: Targeting mitochondria-associated metabolism as a means to enhance nitrogen use efficiency. J. Exp. Bot. 2011, 62, 1467-1482. [CrossRef]

19. Xuan, W.; Beeckman, T.; Xu, G. Plant nitrogen nutrition: Sensing and signaling. Curr. Opin. Plant Biol. 2017, 39, 57-65. [CrossRef]

20. Mur, L.A.; Simpson, C.; Kumari, A.; Gupta, A.K.; Gupta, K.J. Moving nitrogen to the centre of plant defence against pathogens. Ann. Bot. 2017, 119, 703-709. [CrossRef]

21. Bolton, M.D.; Thomma, B.P.H.J. The complexity of nitrogen metabolism and nitrogen-regulated gene expression in plant pathogenic fungi. Physiol. Mol. Plant Pathol. 2008, 72, 104-110. [CrossRef]

22. Huang, H.; Nguyen Thi Thu, T.; He, X.; Gravot, A.; Bernillon, S.; Ballini, E.; Morel, J.B. Increase of Fungal Pathogenicity and Role of Plant Glutamine in Nitrogen-Induced Susceptibility (NIS) To Rice Blast. Front. Plant Sci. 2017, 8, 265. [CrossRef] [PubMed]

23. Devadas, R.; Simpfendorfer, S.; Backhouse, D.; Lamb, D.W. Effect of stripe rust on the yield response of wheat to nitrogen. Crop J. 2014, 2, 201-206. [CrossRef]

24. Ballini, E.; Nguyen, T.T.; Morel, J.B. Diversity and genetics of nitrogen-induced susceptibility to the blast fungus in rice and wheat. Rice 2013, 6, 32. [CrossRef] [PubMed] 
25. Chen, Y.; Zhang, F.; Tang, L.; Zheng, Y.; Li, Y.; Christie, P.; Li, L. Wheat powdery mildew and foliar N concentrations as influenced by $\mathrm{N}$ fertilization and belowground interactions with intercropped faba bean. Plant Soil 2007, 291, 1-13. [CrossRef]

26. Brennan, R.F. Effect of ammonium chloride, ammonium sulphate, and sodium nitrate on take-all and grain yield of wheat grown on soils in South-western Australia. J. Plant Nutr. 1993, 16, 349-358. [CrossRef]

27. Krupinsky, J.M.; Halvorson, A.D.; Tanaka, D.L.; Merrill, S.D. Nitrogen and Tillage Effects on Wheat Leaf Spot Diseases in the Northern Great Plains. Agron. J. 2007, 99, 562. [CrossRef]

28. Brennan, R.F. Effect of superphosphate and nitrogen on yield and take-all of wheat. Fertil. Res. 1992, 31, 43-49. [CrossRef]

29. Lecompte, F.; Ali Abro, M.; Nicot, P.C. Contrasted responses of Botrytis cinerea isolates developing on tomato plants grown under different nitrogen nutrition regimes. Plant Pathol. 2010, 59, 891-899. [CrossRef]

30. Snoeijers, S.S.; Pérez-García, A.; Joosten, M.H.; De Wit, P.J. The effect of nitrogen on disease development and gene expression in bacterial and fungal plant pathogens. Eur. J. Plant Pathol. 2000, 106, 493-506. [CrossRef]

31. Fagard, M.; Launay, A.; Clement, G.; Courtial, J.; Dellagi, A.; Farjad, M.; Krapp, A.; Soulie, M.C.; Masclaux-Daubresse, C. Nitrogen metabolism meets phytopathology. J. Exp. Bot. 2014, 65, 5643-5656. [CrossRef] [PubMed]

32. Govrin, E.M.; Levine, A. The hypersensitive response facilitates plant infection by the necrotrophic pathogen Botrytis cinerea. Curr. Biol. 2000, 10, 751-757. [CrossRef]

33. Richard-Molard, C.; Wuillème, S.; Scheel, C.; Gresshoff, P.M.; Morot-Gaudry, J.F.; Limami, A.M. Nitrogen-induced changes in morphological development and bacterial susceptibility of Belgian endive (Cichorium intybus L.) are genotype-dependent. Planta 1999, 209, 389-398. [CrossRef] [PubMed]

34. Berry, P.M.; Kindred, D.R.; Olesen, J.E.; Jorgensen, L.N.; Paveley, N.D. Quantifying the effect of interactions between disease control, nitrogen supply and land use change on the greenhouse gas emissions associated with wheat production. Plant Pathol. 2010, 59, 753-763. [CrossRef]

35. Brennan, R.F. The role of manganese and nitrogen nutrition in the susceptibility of wheat plants to take-all in Western Australia. Fertil. Res. 1992, 31, 35-41. [CrossRef]

36. poae Landschoot, M. Nitrogen form and rate of nitrogen and chloride application for the control of summer patch in Kentucky bluegrass. Plant Dis. 1995, 79, 51.

37. Elmer, W.H.; LaMondia, J.A. Influence of Ammonium Sulfate and Rotation Crops on Strawberry Black Root Rot. Plant Dis. 1999, 83, 119-123. [CrossRef]

38. Morgan, K.T.; Timmer, L.W. Effect of inoculum density, nitrogen source and saprophytic fungi on Fusarium wilt of Mexican lime. Plant Soil 1984, 79, 203-210. [CrossRef]

39. Wang, M.; Sun, Y.; Gu, Z.; Wang, R.; Sun, G.; Zhu, C.; Guo, S.; Shen, Q. Nitrate Protects Cucumber Plants Against Fusarium oxysporum by Regulating Citrate Exudation. Plant Cell Physiol. 2016, 57, 2001-2012. [CrossRef]

40. Neumann, S.; Paveley, N.D.; Beed, F.D.; Sylvester-Bradley, R. Nitrogen per unit leaf area affects the upper asymptote of Puccinia striiformis f. sp. tritici epidemics in winter wheat. Plant Pathol. 2004, 53, 725-732.

41. Dordas, C. Role of nutrients in controlling plant diseases in sustainable agriculture. A review. Agron. Sustain. Dev. 2008, 28, 33-46. [CrossRef]

42. Solomon, P.S.; Oliver, R.P. Evidence that $\gamma$-aminobutyric acid is a major nitrogen source during Cladosporium fulvum infection of tomato. Planta 2002, 214, 414-420. [CrossRef] [PubMed]

43. Bönnighausen, J.; Gebhard, D.; Kröger, C.; Hadeler, B.; Tumforde, T.; Lieberei, R.; Bergemann, J.; Schäfer, W.; Bormann, J. Disruption of the GABA shunt affects mitochondrial respiration and virulence in the cereal pathogen Fusarium graminearum. Mol. Microbiol. 2015, 98, 1115-1132. [CrossRef] [PubMed]

44. Zhou, J.; Wang, M.; Sun, Y.; Gu, Z.; Wang, R.; Saydin, A.; Shen, Q.; Guo, S. Nitrate Increased Cucumber Tolerance to Fusarium Wilt by Regulating Fungal Toxin Production and Distribution. Toxins 2017, 9, 100. [CrossRef] [PubMed]

45. Divon, H.H.; Ziv, C.; Davydov, O.; Yarden, O.; Fluhr, R. The global nitrogen regulator, FNR1, regulates fungal nutrition-genes and fitness during Fusarium oxysporum pathogenesis. Mol. Plant Pathol. 2006, 7, 485-497. [CrossRef]

46. Tenuta, M.; Lazarovits, G. Ammonia and nitrous acid from nitrogenous amendments kill the microsclerotia of Verticillium dahliae. Phytopathology 2002, 92, 255-264. [CrossRef] 
47. Wang, L.; Bau, H.; Liao, H.; Chung, K. Factors affecting the production of elsinochrome phytotoxin by the citrus scab pathogen, Elsinoë fawcettii. Open Mycol. J. 2009, 3, 1-8. [CrossRef]

48. Calvo, A.M.; Wilson, R.A.; Bok, J.W.; Keller, N.P. Relationship between secondary metabolism and fungal development. Microbiol. Mol. Biol. Rev. 2002, 66, 447-459. [CrossRef]

49. Datnoff, L.E.; Elmer, W.H.; Huber, D.M. Mineral Nutrition and Plant Disease; American Phytopathological Society: St. Paul, AK, USA, 2007.

50. Pérez-García, A.; Snoeijers, S.S.; Joosten, M.H.; Goosen, T.; De Wit, P.J. Expression of the avirulence gene Avr9 of the fungal tomato pathogen Cladosporium fulvum is regulated by the global nitrogen response factor NRF1. Mol. Plant Microbe Interact. 2001, 14, 316-325. [CrossRef]

51. Donofrio, N.M.; Oh, Y.; Lundy, R.; Pan, H.; Brown, D.E.; Jeong, J.S.; Coughlan, S.; Mitchell, T.K.; Dean, R.A. Global gene expression during nitrogen starvation in the rice blast fungus, Magnaporthe grisea. Fungal Genet. Biol. 2006, 43, 605-617. [CrossRef]

52. Thomma, B.P.; HP, V.A.N.E.; Crous, P.W.; PJ, D.E.W. Cladosporium fulvum (syn. Passalora fulva), a highly specialized plant pathogen as a model for functional studies on plant pathogenic Mycosphaerellaceae. Mol. Plant Pathol. 2005, 6, 379-393. [CrossRef] [PubMed]

53. Prior, S.A.; Pritchard, S.G.; Runion, G.B.; Rogers, H.H.; Mitchell, R.J. Influence of atmospheric $\mathrm{CO}_{2}$ enrichment, soil N, and water stress on needle surface wax formation in Pinus palustris (Pinaceae). Am. J. Bot. 1997, 84, 1070-1077. [CrossRef] [PubMed]

54. Mrnka, L.; Tokárová, H.; Vosátka, M.; Matějka, P. Interaction of soil filamentous fungi affects needle composition and nutrition of Norway spruce seedlings. Trees 2009, 23, 887-897. [CrossRef]

55. Plavcova, L.; Hacke, U.G.; Almeida-Rodriguez, A.M.; Li, E.; Douglas, C.J. Gene expression patterns underlying changes in xylem structure and function in response to increased nitrogen availability in hybrid poplar. Plant Cell Environ. 2013, 36, 186-199. [CrossRef]

56. Camargo, E.L.O.; Nascimento, L.C.; Soler, M.; Salazar, M.M.; Lepikson-Neto, J.; Marques, W.L.; Alves, A.; Teixeira, P.J.P.L.; Mieczkowski, P.; Carazzolle, M.F.; et al. Contrasting nitrogen fertilization treatments impact xylem gene expression and secondary cell wall lignification in Eucalyptus. BMC Plant Biol. 2014, 14, 256. [CrossRef]

57. Zhang, W.; Wu, L.; Ding, Y.; Yao, X.; Wu, X.; Weng, F.; Li, G.; Liu, Z.; Tang, S.; Ding, C.; et al. Nitrogen fertilizer application affects lodging resistance by altering secondary cell wall synthesis in japonica rice (Oryza sativa). J. Plant Res. 2017, 130, 859-871. [CrossRef]

58. Sun, Q.; Liu, X.; Yang, J.; Liu, W.; Du, Q.; Wang, H.; Fu, C.; Li, W. MicroRNA528 Affects Lodging Resistance of Maize by Regulating Lignin Biosynthesis under Nitrogen-Luxury Conditions. Mol. Plant 2018, 11, 806-814. [CrossRef]

59. Zhang, W.; Wu, L.; Wu, X.; Ding, Y.; Li, G.; Li, J.; Weng, F.; Liu, Z.; Tang, S.; Ding, C.; et al. Lodging Resistance of Japonica Rice (Oryza Sativa L.): Morphological and Anatomical Traits due to top-Dressing Nitrogen Application Rates. Rice 2016, 9, 31. [CrossRef]

60. Kováčik, J.; Klejdus, B.; Bačkor, M.; Repčák, M. Phenylalanine ammonia-lyase activity and phenolic compounds accumulation in nitrogen-deficient Matricaria chamomilla leaf rosettes. Plant Sci. 2007, 172, 393-399. [CrossRef]

61. Jauset, A.M.; Sarasua, M.J.; Avilla, J.; Albajes, R. Effect of nitrogen fertilization level applied to tomato on the greenhouse whitefly. Crop Prot. 2000, 19, 255-261. [CrossRef]

62. Daane, K.; Johnson, R.; Michailides, T.; Crisosto, C.; Dlott, J.; Ramirez, H.; Morgan, D. Excess nitrogen raises nectarine susceptibility to disease and insects. Calif. Agric. 1995, 49, 13-18. [CrossRef]

63. Tronchet, M.; Balague, C.; Kroj, T.; Jouanin, L.; Roby, D. Cinnamyl alcohol dehydrogenases-C and D, key enzymes in lignin biosynthesis, play an essential role in disease resistance in Arabidopsis. Mol. Plant Pathol. 2010, 11, 83-92. [CrossRef] [PubMed]

64. Nobuaki, M. The effect of ample nitrogen fertilizer on cell-wall materials and its significance to rice blast disease. Ann. Phytopathol. Soc. Jpn. 1975, 41, 56-61.

65. Wilson, R.A.; Talbot, N.J. Under pressure: Investigating the biology of plant infection by Magnaporthe oryzae. Nat. Rev. Microbiol. 2009, 7, 185. [CrossRef]

66. Blanke, M.M.; Bacher, W.; Pring, R.J.; Baker, E.A. Ammonium nutrition enhances chlorophyll and glaucousness in kohlrabi. Ann. Bot. 1996, 78, 599-604. [CrossRef] 
67. Wang, C.; Zhang, S.H.; Wang, P.F.; Li, W.; Lu, J. Effects of ammonium on the antioxidative response in Hydrilla verticillata (Lf) Royle plants. Ecotoxicol. Environ. Saf. 2010, 73, 189-195. [CrossRef]

68. Massad, T.J.; Dyer, L.A.; Vega, C.G. Costs of defense and a test of the carbon-nutrient balance and growth-differentiation balance hypotheses for two co-occurring classes of plant defense. PLoS ONE 2012, 7, e47554. [CrossRef]

69. Royer, M.; Larbat, R.; Le Bot, J.; Adamowicz, S.; Robin, C. Is the C:N ratio a reliable indicator of C allocation to primary and defence-related metabolisms in tomato? Phytochemistry 2013, 88, 25-33. [CrossRef]

70. Samuels, L.; Kunst, L.; Jetter, R. Sealing Plant Surfaces: Cuticular Wax Formation by Epidermal Cells. Annu. Rev. Plant Biol. 2008, 59, 683-707. [CrossRef]

71. Wang, M.; Gu, Z.; Wang, R.; Guo, J.; Ling, N.; Firbank, L.G.; Guo, S. Plant primary metabolism regulated by nitrogen contributes to plant-pathogen interactions. Plant Cell Physiol. 2018, 60, 329-342. [CrossRef]

72. Zeier, J. New insights into the regulation of plant immunity by amino acid metabolic pathways. Plant Cell Environ. 2013, 36, 2085-2103. [CrossRef] [PubMed]

73. Ngadze, E.; Icishahayo, D.; Coutinho, T.A.; van der Waals, J.E. Role of Polyphenol Oxidase, Peroxidase, Phenylalanine Ammonia Lyase, Chlorogenic Acid, and Total Soluble Phenols in Resistance of Potatoes to Soft Rot. Plant Dis. 2012, 96, 186-192. [CrossRef] [PubMed]

74. Thomma, B.P.; Nelissen, I.; Eggermont, K.; Broekaert, W.F. Deficiency in phytoalexin production causes enhanced susceptibility of Arabidopsis thaliana to the fungus Alternaria brassicicola. Plant J. 1999, 19, 163-171. [CrossRef] [PubMed]

75. Gnonlonfin, G.J.B.; Sanni, A.; Brimer, L. Review Scopoletin-A Coumarin Phytoalexin with Medicinal Properties. Crit. Rev. Plant Sci. 2012, 31, 47-56. [CrossRef]

76. Schlaeppi, K.; Abou-Mansour, E.; Buchala, A.; Mauch, F. Disease resistance of Arabidopsis to Phytophthora brassicae is established by the sequential action of indole glucosinolates and camalexin. Plant J. 2010, 62, 840-851. [CrossRef] [PubMed]

77. Schmelz, E.A.; Kaplan, F.; Huffaker, A.; Dafoe, N.J.; Vaughan, M.M.; Ni, X.; Rocca, J.R.; Alborn, H.T.; Teal, P.E. Identity, regulation, and activity of inducible diterpenoid phytoalexins in maize. Proc. Natl. Acad. Sci. USA 2011, 108, 5455-5460. [CrossRef]

78. De Long, J.R.; Sundqvist, M.K.; Gundale, M.J.; Giesler, R.; Wardle, D.A.; Rasmann, S. Effects of elevation and nitrogen and phosphorus fertilization on plant defence compounds in subarctic tundra heath vegetation. Funct. Ecol. 2016, 30, 314-325. [CrossRef]

79. Dormann, C.F. Consequences of manipulations in carbon and nitrogen supply for concentration of anti-herbivore defence compounds in Salix polaris. Écoscience 2016, 10, 312-318. [CrossRef]

80. Khanna, A.Q.; Borowicz, V.A.; Jones, M.A. Effects of nitrogen fertilizer and defoliation on growth, foliar nitrogen and foliar coumestrol concentrations of soybean. Trans. Ill. State Acad. Sci. 1999, 92, 167-179.

81. Tomova, L.; Braun, S.; Flückiger, W. The effect of nitrogen fertilization on fungistatic phenolic compounds in roots of beech (Fagus sylvatica) and Norway spruce (Picea abies). For. Pathol. 2005, 35, 262-276. [CrossRef]

82. Bhaskar, C.V.; Rao, G.R.; Reddy, K.B. Effect of nitrogen and potassium nutrition on sheath rot incidence and phenol content in rice (Oryza sativa L.). Indian J. Plant Physiol. 2001, 6, 254-257.

83. Keller, M.; Rogiers, S.Y.; Schultz, H.R. Nitrogen and ultraviolet radiation modify grapevines' susceptibility to powdery mildew. Vitis-Geilweilerhof 2003, 42, 87-94.

84. Thalineau, E.; Fournier, C.; Gravot, A.; Wendehenne, D.; Jeandroz, S.; Truong, H.N. Nitrogen modulation of Medicago truncatula resistance to Aphanomyces euteiches depends on plant genotype. Mol. Plant Pathol. 2018, 19, 664-676. [CrossRef] [PubMed]

85. Mittelstrass, K.; Treutter, D.; Plessl, M.; Heller, W.; Elstner, E.F.; Heiser, I. Modification of primary and secondary metabolism of potato plants by nitrogen application differentially affects resistance to Phytophthora infestans and Alternaria solani. Plant Biol. 2006, 8, 653-661. [CrossRef] [PubMed]

86. Leser, C.; Treutter, D. Effects of nitrogen supply on growth, contents of phenolic compounds and pathogen (scab) resistance of apple trees. Physiol. Plant. 2005, 123, 49-56. [CrossRef]

87. Wu, C.H.; Dewir, Y.H.; Hahn, E.J.; Paek, K.Y. Optimization of culturing conditions for the production of biomass and phenolics from adventitious roots of Echinacea angustifolia. J. Plant Biol. 2006, 49, 193. [CrossRef]

88. Cui, X.; Murthy, H.N.; Wu, C.; Paek, K. Adventitious root suspension cultures of Hypericum perforatum: Effect of nitrogen source on production of biomass and secondary metabolites. In Vitro Cell. Dev. Plant 2010, 46, 437-444. [CrossRef] 
89. Fallovo, C.; Schreiner, M.; Schwarz, D.; Colla, G.; Krumbein, A. Phytochemical changes induced by different nitrogen supply forms and radiation levels in two leafy Brassica species. J. Agric. Food Chem. 2011, 59, 4198-4207. [CrossRef]

90. Zhang, Y.H.; Zhong, J.J.; Yu, J.T. Effect of nitrogen source on cell growth and production of ginseng saponin and polysaccharide in suspension cultures of Panax notoginseng. Biotechnol. Prog. 1996, 12, 567-571. [CrossRef]

91. Wang, J.W.; Tan, R.X. Artemisinin production in Artemisia annua hairy root cultures with improved growth by altering the nitrogen source in the medium. Biotechnol. Lett. 2002, 24, 1153-1156. [CrossRef]

92. Zhang, J.; Gao, W.; Wang, J.; Li, X.; Xiao, P. Improvement of growth and periplocin yield of Periploca sepium adventitious root cultures by altering nitrogen source supply. Chin. Herb. Med. 2011, 3, 226-231.

93. Jin, X.; Hao, N.; Jiao, F.; Yang, Y.; Wang, D.; Xu, C.; Zhai, R. The effect of nitrogen supply on potato yield, tuber size and pathogen resistance in Solanum tuberosum exposed to Phytophthora infestans. Afr. J. Agric. Res. 2014, 9, 657-2663.

94. Matros, A.; Amme, S.; Kettig, B.; Buck-Sorlin, G.H.; Sonnewald, U.W.E.; Mock, H.P. Growth at elevated $\mathrm{CO}_{2}$ concentrations leads to modified profiles of secondary metabolites in tobacco cv. SamsunNN and to increased resistance against infection with potato virus Y. Plant Cell Environ. 2006, 29, 126-137. [CrossRef] [PubMed]

95. Konishi, H.; Ishiguro, K.; Komatsu, S. A proteomics approach towards understanding blast fungus infection of rice grown under different levels of nitrogen fertilization. Proteomics 2001, 1, 1162-1171. [CrossRef]

96. Thapa, S.; Prasanna, R.; Ramakrishnan, B.; Sheoran, N.; Kumar, A.; Velmourougane, K.; Kumar, A. Interactive effects of Magnaporthe inoculation and nitrogen doses on the plant enzyme machinery and phyllosphere microbiome of resistant and susceptible rice cultivars. Arch. Microbiol. 2018, 200, 1287-1305. [CrossRef]

97. González-Hernández, A.I.; Fernández-Crespo, E.; Scalschi, L.; Hajirezaei, M.-R.; von Wirén, N.; García-Agustín, P.; Camañes, G. Ammonium mediated changes in carbon and nitrogen metabolisms induce resistance against Pseudomonas syringae in tomato plants. J. Plant Physiol. 2019, 239, 28-37. [CrossRef]

98. Sarhan, A.R.T.; Barna, B.; Kiraly, Z. Effect of nitrogen nutrition on Fusarium wilt of tomato plants. Ann. Appl. Biol. 1982, 101, 245-250. [CrossRef]

99. Anand, A.; Zhou, T.; Trick, H.N.; Gill, B.S.; Bockus, W.W.; Muthukrishnan, S. Greenhouse and field testing of transgenic wheat plants stably expressing genes for thaumatin-like protein, chitinase and glucanase against Fusarium graminearum. J. Exp. Bot. 2003, 54, 1101-1111. [CrossRef]

100. Sarowar, S.; Kim, Y.J.; Kim, E.N.; Kim, K.D.; Hwang, B.K.; Islam, R.; Shin, J.S. Overexpression of a pepper basic pathogenesis-related protein 1 gene in tobacco plants enhances resistance to heavy metal and pathogen stresses. Plant Cell Rep. 2005, 24, 216-224. [CrossRef]

101. Lian, X.; Wang, S.; Zhang, J.; Feng, Q.; Zhang, L.; Fan, D.; Li, X.; Yuan, D.; Han, B.; Zhang, Q. Expression profiles of 10,422 genes at early stage of low nitrogen stress in rice assayed using a cDNA microarray. Plant Mol. Biol. 2006, 60, 617-631. [CrossRef]

102. Vega, A.; Canessa, P.; Hoppe, G.; Retamal, I.; Moyano, T.C.; Canales, J.; Gutierrez, R.A.; Rubilar, J. Transcriptome analysis reveals regulatory networks underlying differential susceptibility to Botrytis cinerea in response to nitrogen availability in Solanum lycopersicum. Front. Plant Sci. 2015, 6, 911. [CrossRef] [PubMed]

103. Kruse, C.; Jost, R.; Lipschis, M.; Kopp, B.; Hartmann, M.; Hell, R. Sulfur-enhanced defence: Effects of sulfur metabolism, nitrogen supply, and pathogen lifestyle. Plant Biol. 2007, 9, 608-619. [CrossRef] [PubMed]

104. Lopes, J.L.; Valadares, N.F.; Moraes, D.I.; Rosa, J.C.; Araujo, H.S.; Beltramini, L.M. Physico-chemical and antifungal properties of protease inhibitors from Acacia plumosa. Phytochemistry 2009, 70, 871-879. [CrossRef] [PubMed]

105. Cipollini, D.F.; Bergelson, J. Plant density and nutrient availability constrain constitutive and wound-induced expression of trypsin inhibitors in Brassica napus. J. Chem. Ecol. 2001, 27, 593-610. [CrossRef] [PubMed]

106. Krishnan, H.B.; Bennett, J.O.; Kim, W.S.; Krishnan, A.H.; Mawhinney, T.P. Nitrogen lowers the sulfur amino acid content of soybean (Glycine max [L.] Merr.) by regulating the accumulation of Bowman-Birk protease inhibitor. J. Agric. Food Chem. 2005, 53, 6347-6354. [CrossRef] [PubMed]

107. Stout, M.J.; Brovont, R.A.; Duffey, S.S. Effect of nitrogen availability on expression of constitutive and inducible chemical defenses in tomato, Lycopersicon esculentum. J. Chem. Ecol. 1998, 24, 945-963. [CrossRef]

108. Solomon, P.S.; Tan, K.C.; Oliver, R.P. The nutrient supply of pathogenic fungi; a fertile field for study. Mol. Plant Pathol. 2003, 4, 203-210. [CrossRef] 
109. Påhlsson, A.M.B. Influence of nitrogen fertilization on minerals, carbohydrates, amino acids and phenolic compounds in beech (Fagus sylvatica L.) leaves. Tree Physiol. 1992, 10, 93-100. [CrossRef]

110. Seifi, H.; De Vleesschauwer, D.; Aziz, A.; Hofte, M. Modulating plant primary amino acid metabolism as a necrotrophic virulence strategy: The immune-regulatory role of asparagine synthetase in Botrytis cinerea-tomato interaction. Plant Signal. Behav. 2014, 9, e27995. [CrossRef]

111. Sonderby, I.E.; Geu-Flores, F.; Halkier, B.A. Biosynthesis of glucosinolates-gene discovery and beyond. Trends Plant Sci. 2010, 15, 283-290. [CrossRef]

112. Yan, X.; Chen, S. Regulation of plant glucosinolate metabolism. Planta 2007, 226, 1343-1352. [CrossRef]

113. Adio, A.M.; Casteel, C.L.; De Vos, M.; Kim, J.H.; Joshi, V.; Li, B.; Juery, C.; Daron, J.; Kliebenstein, D.J.; Jander, G. Biosynthesis and defensive function of Ndelta-acetylornithine, a jasmonate-induced Arabidopsis metabolite. Plant Cell 2011, 23, 3303-3318. [CrossRef]

114. Chen, J.; Zhang, Y.; Wang, C.; Lu, W.; Jin, J.B.; Hua, X. Proline induces calcium-mediated oxidative burst and salicylic acid signaling. Amino Acids 2011, 40, 1473-1484. [CrossRef] [PubMed]

115. Hwang, I.S.; An, S.H.; Hwang, B.K. Pepper asparagine synthetase 1 (CaAS1) is required for plant nitrogen assimilation and defense responses to microbial pathogens. Plant J. 2011, 67, 749-762. [CrossRef] [PubMed]

116. Brauc, S.; De Vooght, E.; Claeys, M.; Höfte, M.; Angenon, G. Influence of over-expression of cytosolic aspartate aminotransferase on amino acid metabolism and defence responses against Botrytis cinerea infection in Arabidopsis thaliana. J. Plant Physiol. 2011, 168, 1813-1819. [CrossRef] [PubMed]

117. Liu, G.; Ji, Y.; Bhuiyan, N.H.; Pilot, G.; Selvaraj, G.; Zou, J.; Wei, Y. Amino acid homeostasis modulates salicylic acid-associated redox status and defense responses in Arabidopsis. Plant Cell 2010, 22, 3845-3863. [CrossRef] [PubMed]

118. Gupta, K.J.; Brotman, Y.; Segu, S.; Zeier, T.; Zeier, J.; Persijn, S.T.; Cristescu, S.M.; Harren, F.J.; Bauwe, H.; Fernie, A.R.; et al. The form of nitrogen nutrition affects resistance against Pseudomonas syringae pv. phaseolicola in tobacco. J. Exp. Bot. 2013, 64, 553-568. [CrossRef]

119. Cowley, T.; Walters, D.R. Polyamine metabolism in barley reacting hypersensitively to the powdery mildew fungus Blumeria graminis f. sp. hordei. Plant Cell Environ. 2002, 25, 461-468. [CrossRef]

120. Taler, D.; Galperin, M.; Benjamin, I.; Cohen, Y.; Kenigsbuch, D. Plant $e R$ genes that encode photorespiratory enzymes confer resistance against disease. Plant Cell 2004, 16, 172-184. [CrossRef]

121. Bloom, A.J. Photorespiration and nitrate assimilation: A major intersection between plant carbon and nitrogen. Photosynth. Res. 2015, 123, 117-128. [CrossRef]

122. Dixon, R.A.; Achnine, L.; Kota, P.; Liu, C.J.; Reddy, M.S.; Wang, L. The phenylpropanoid pathway and plant defence-A genomics perspective. Mol. Plant Pathol. 2002, 3, 371-390. [CrossRef] [PubMed]

123. Peng, M.; Bi, Y.; Zhu, T.; Rothstein, S.J. Genome-wide analysis of Arabidopsis responsive transcriptome to nitrogen limitation and its regulation by the ubiquitin ligase gene NLA. Plant Mol. Biol. 2007, 65, 775-797. [CrossRef] [PubMed]

124. Sun, Y.; Hou, M.; Mur, L.A.; Yang, Y.; Zhang, T.; Xu, X.; Huang, S.; Tong, H. Nitrogen drives plant growth to the detriment of leaf sugar and steviol glycosides metabolisms in Stevia (Stevia rebaudiana Bertoni). Plant Physiol. Biochem. 2019, 141, 240-249. [CrossRef] [PubMed]

125. Lou, Y.; Baldwin, I.T. Nitrogen supply influences herbivore-induced direct and indirect defenses and transcriptional responses in Nicotiana attenuata. Plant Physiol. 2004, 135, 496-506. [CrossRef] [PubMed]

126. De Gara, L.; de Pinto, M.C.; Tommasi, F. The antioxidant systems vis-à-vis reactive oxygen species during plant-pathogen interaction. Plant Physiol. Biochem. 2003, 41, 863-870. [CrossRef]

127. Yao, X.; Liu, Q. Changes in photosynthesis and antioxidant defenses of Picea asperata seedlings to enhanced ultraviolet-B and to nitrogen supply. Physiol. Plant. 2006, 129, 364-374. [CrossRef]

128. Campos, F.G.; Vieira, M.A.R.; Amaro, A.C.E.; delaCruz-Chacon, I.; Marques, M.O.M.; Ferreira, G.; Boaro, C.S.F. Nitrogen in the defense system of Annona emarginata (Schltdl.) H. Rainer. PLoS ONE 2019, 14, e0217930. [CrossRef]

129. Lin, Y.; Chao, Y.; Huang, W.; Kao, C. Effect of nitrogen deficiency on antioxidant status and Cd toxicity in rice seedlings. Plant Growth Regul. 2011, 64, 263-273. [CrossRef]

130. Kovacik, J.; Klejdus, B.; Backor, M. Nitric oxide signals ROS scavenger-mediated enhancement of PAL activity in nitrogen-deficient Matricaria chamomilla roots: Side effects of scavengers. Free Radic. Biol. Med. 2009, 46, 1686-1893. [CrossRef] 
131. Kong, L.; Wang, F.; Si, J.; Feng, B.; Zhang, B.; Li, S.; Wang, Z. Increasing in ROS levels and callose deposition in peduncle vascular bundles of wheat (Triticum aestivum L.) grown under nitrogen deficiency. J. Plant Interact. 2013, 8, 109-116. [CrossRef]

132. Ali, S.; Farooq, M.A.; Jahangir, M.M.; Abbas, F.; Bharwana, S.A.; Zhang, G.P. Effect of chromium and nitrogen form on photosynthesis and anti-oxidative system in barley. Biol. Plant. 2013, 57, 758-763. [CrossRef]

133. Rios-Gonzalez, K.; Erdei, L.; Lips, S.H. The activity of antioxidant enzymes in maize and sunflower seedlings as affected by salinity and different nitrogen sources. Plant Sci. 2002, 162,923-930. [CrossRef]

134. Begara-Morales, J.C.; Sanchez-Calvo, B.; Chaki, M.; Valderrama, R.; Mata-Perez, C.; Padilla, M.N.; Corpas, F.J.; Barroso, J.B. Antioxidant Systems are Regulated by Nitric Oxide-Mediated Post-translational Modifications (NO-PTMs). Front. Plant Sci. 2016, 7, 152. [CrossRef] [PubMed]

135. Dominguez-Valdivia, M.D.; Aparicio-Tejo, P.M.; Lamsfus, C.; Cruz, C.; Martins-Loucao, M.A.; Moran, J.F. Nitrogen nutrition and antioxidant metabolism in ammonium-tolerant and -sensitive plants. Physiol. Plant 2008, 132, 359-369. [CrossRef] [PubMed]

136. Devadas, S.K.; Enyedi, A.; Raina, R. The Arabidopsis hrl1 mutation reveals novel overlapping roles for salicylic acid, jasmonic acid and ethylene signalling in cell death and defence against pathogens. Plant J. 2002, 30, 467-480. [CrossRef]

137. Yaeno, T.; Iba, K. BAH1/NLA, a RING-type ubiquitin E3 ligase, regulates the accumulation of salicylic acid and immune responses to Pseudomonas syringae DC3000. Plant Physiol. 2008, 148, 1032-1041. [CrossRef] [PubMed]

138. Maekawa, S.; Sato, T.; Asada, Y.; Yasuda, S.; Yoshida, M.; Chiba, Y.; Yamaguchi, J. The Arabidopsis ubiquitin ligases ATL31 and ATL6 control the defense response as well as the carbon/nitrogen response. Plant Mol. Biol. 2012, 79, 217-227. [CrossRef]

139. Pieterse, C.M.; Leon-Reyes, A.; Van der Ent, S.; Van Wees, S.C. Networking by small-molecule hormones in plant immunity. Nat. Chem. Biol. 2009, 5, 308. [CrossRef]

140. Scalschi, L.; Sanmartín, M.; Camañes, G.; Troncho, P.; Sánchez-Serrano, J.J.; García-Agustín, P.; Vicedo, B. Silencing of OPR 3 in tomato reveals the role of OPDA in callose deposition during the activation of defense responses against Botrytis cinerea. Plant J. 2015, 81, 304-315. [CrossRef]

141. Farjad, M.; Rigault, M.; Pateyron, S.; Martin-Magniette, M.L.; Krapp, A.; Meyer, C.; Fagard, M. Nitrogen Limitation Alters the Response of Specific Genes to Biotic Stress. Int. J. Mol. Sci. 2018, 19, 3364. [CrossRef]

142. Berens, M.L.; Berry, H.M.; Mine, A.; Argueso, C.T.; Tsuda, K. Evolution of hormone signaling networks in plant defense. Annu. Rev. Phytopathol. 2017, 55, 401-425. [CrossRef] [PubMed]

143. Oka, M.; Shimoda, Y.; Sato, N.; Inoue, J.; Yamazaki, T.; Shimomura, N.; Fujiyama, H. Abscisic acid substantially inhibits senescence of cucumber plants (Cucumis sativus) grown under low nitrogen conditions. J. Plant Physiol. 2012, 169, 789-796. [CrossRef] [PubMed]

144. Garnica, M.; Houdusse, F.; Zamarreno, A.M.; Garcia-Mina, J.M. The signal effect of nitrate supply enhances active forms of cytokinins and indole acetic content and reduces abscisic acid in wheat plants grown with ammonium. J. Plant Physiol. 2010, 167, 1264-1272. [CrossRef] [PubMed]

145. Mur, L.A.; Prats, E.; Pierre, S.; Hall, M.A.; Hebelstrup, K.H. Integrating nitric oxide into salicylic acid and jasmonic acid/ ethylene plant defense pathways. Front. Plant Sci. 2013, 4, 215. [CrossRef]

146. Mur, L.A.; Santosa, I.E.; Laarhoven, L.J.; Holton, N.J.; Harren, F.J.; Smith, A.R. Laser photoacoustic detection allows in planta detection of nitric oxide in tobacco following challenge with avirulent and virulent Pseudomonas syringae Pathovars. Plant Physiol. 2005, 138, 1247-1258. [CrossRef]

147. Chen, J.; Vandelle, E.; Bellin, D.; Delledonne, M. Detection and function of nitric oxide during the hypersensitive response in Arabidopsis thaliana: Where there's a will there's a way. Nitric Oxide 2014, 43, 81-88. [CrossRef]

148. Wang, Y.; Loake, G.J.; Chu, C. Cross-talk of nitric oxide and reactive oxygen species in plant programed cell death. Front. Plant Sci. 2013, 4, 314. [CrossRef]

149. Modolo, L.V. Nitric Oxide Synthase-Mediated Phytoalexin Accumulation in Soybean Cotyledons in Response to the Diaporthe phaseolorum f. sp. meridionalis Elicitor. Plant Physiol. 2002, 130, 1288-1297. [CrossRef]

150. Modolo, L.V.; Augusto, O.; Almeida, I.M.G.; Magalhaes, J.R.; Salgado, I. Nitrite as the major source of nitric oxide production by Arabidopsis thalianain response to Pseudomonas syringae. FEBS Lett. 2005, 579, 3814-3820. [CrossRef] 
151. Modolo, L.V.; Augusto, O.; Almeida, I.M.G.; Pinto-Maglio, C.A.F.; Oliveira, H.C.; Seligman, K.; Salgado, I. Decreased arginine and nitrite levels in nitrate reductase-deficient Arabidopsis thaliana plants impair nitric oxide synthesis and the hypersensitive response to Pseudomonas syringae. Plant Sci. 2006, 171, 34-40. [CrossRef]

152. Vitor, S.C.; Duarte, G.T.; Saviani, E.E.; Vincentz, M.G.; Oliveira, H.C.; Salgado, I. Nitrate reductase is required for the transcriptional modulation and bactericidal activity of nitric oxide during the defense response of Arabidopsis thaliana against Pseudomonas syringae. Planta 2013, 238, 475-486. [CrossRef] [PubMed]

153. Camañes, G.; Pastor, V.; Cerezo, M.; García-Andrade, J.; Vicedo, B.; García-Agustín, P.; Flors, V.A. Deletion in NRT2.1 Attenuates Pseudomonas syringae-Induced Hormonal Perturbation, Resulting in Primed Plant Defenses. Plant Physiol. 2012, 158, 1054-1066. [CrossRef] [PubMed]

154. Wang, H.; Lu, Y.; Liu, P.; Wen, W.; Zhang, J.; Ge, X.; Xia, Y. The ammonium/nitrate ratio is an input signal in the temperature-modulated, SNC1-mediated and EDS1-dependent autoimmunity of nudt6-2 nudt7. Plant J. 2013, 73, 262-275. [CrossRef] [PubMed]

155. Mur, L.A.; Kumari, A.; Brotman, Y.; Zeier, J.; Mandon, J.; Cristescu, S.M.; Harren, F.; Kaiser, W.M.; Fernie, A.R.; Gupta, K.J. Nitrite and nitric oxide are important in the adjustment of primary metabolism during the hypersensitive response in tobacco. J. Exp. Bot. 2019, 70, 4571-4582. [CrossRef] [PubMed]

156. Mur, L.A.; Sivakumaran, A.; Mandon, J.; Cristescu, S.M.; Harren, F.J.; Hebelstrup, K.H. Haemoglobin modulates salicylate and jasmonate/ethylene-mediated resistance mechanisms against pathogens. J. Exp. Bot. 2012, 63, 4375-4387. [CrossRef]

157. Chun, H.J.; Park, H.C.; Koo, S.C.; Lee, J.H.; Park, C.Y.; Choi, M.S.; Kang, C.H.; Baek, D.; Cheong, Y.H.; Yun, D.J. Constitutive expression of mammalian nitric oxide synthase in tobacco plants triggers disease resistance to pathogens. Mol. Cells 2012, 34, 463-471. [CrossRef]

158. Lindermayr, C.; Sell, S.; Müller, B.; Leister, D.; Durner, J. Redox Regulation of the NPR1-TGA1 System of Arabidopsis thaliana by Nitric Oxide. Plant Cell 2010, 22, 2894-2907. [CrossRef]

159. Zimerman-Lax, N.; Shenker, M.; Tamir-Ariel, D.; Perl-Treves, R.; Burdman, S. Effects of nitrogen nutrition on disease development caused by Acidovorax citrulli on melon foliage. Eur. J. Plant Pathol. 2015, 145, 125-137. [CrossRef]

160. Zhang, F.; Wan, X.; Zheng, Y.; Sun, L.; Chen, Q.; Zhu, X.; Guo, Y.; Liu, M. Effects of nitrogen on the activity of antioxidant enzymes and gene expression in leaves of Populus plants subjected to cadmium stress. J. Plant Interact. 2014, 9, 599-609. [CrossRef]

161. Liang, C.; Wang, Y.; Zhu, Y.; Tang, J.; Hu, B.; Liu, L.; Ou, S.; Wu, H.; Sun, X.; Chu, J. OsNAP connects abscisic acid and leaf senescence by fine-tuning abscisic acid biosynthesis and directly targeting senescence-associated genes in rice. Proc. Natl. Acad. Sci. USA 2014, 111, 10013-10018. [CrossRef]

162. Zhou, Y.; Huang, W.; Liu, L.; Chen, T.; Zhou, F.; Lin, Y. Identification and functional characterization of a rice NAC gene involved in the regulation of leaf senescence. BMC Plant Biol. 2013, 13, 132. [CrossRef]

163. Seifi, H.S.; Van Bockhaven, J.; Angenon, G.; Hofte, M. Glutamate metabolism in plant disease and defense: Friend or foe? Mol. Plant Microbe Interact. 2013, 26, 475-485. [CrossRef]

164. Pastor, V.; Gamir, J.; Camañes, G.; Cerezo, M.; Sánchez-Bel, P.; Flors, V. Disruption of the ammonium transporter AMT1.1 alters basal defenses generating resistance against Pseudomonas syringae and Plectosphaerella cucumerina. Front. Plant Sci. 2014, 5, 231. [CrossRef] [PubMed]

165. Durrant, W.E.; Dong, X. Systemic acquired resistance. Annu. Rev. Phytopathol. 2004, 42, 185-209. [CrossRef] [PubMed]

166. Mandal, S.; Mallick, N.; Mitra, A. Salicylic acid-induced resistance to Fusarium oxysporum f. sp. lycopersici in tomato. Plant Physiol. Biochem. 2009, 47, 642-649. [CrossRef] [PubMed]

167. PiterkovÁ, J.; PetŘIvalskÝ, M.; LuhovÁ, L.; MieslerovÁ, B.; SedlÁŘOvÁ, M.; Lebeda, A. Local and systemic production of nitric oxide in tomato responses to powdery mildew infection. Mol. Plant Pathol. 2009, 10, 501-513. [CrossRef]

168. Wang, C.; El-Shetehy, M.; Shine, M.B.; Yu, K.; Navarre, D.; Wendehenne, D.; Kachroo, A.; Kachroo, P. Free radicals mediate systemic acquired resistance. Cell Rep. 2014, 7, 348-355. [CrossRef]

169. Yang, H.; Ludewig, U. Lysine catabolism, amino acid transport, and systemic acquired resistance: What is the link? Plant Signal. Behav. 2014, 9, e28933. [CrossRef] 
170. Bernsdorff, F.; Doring, A.C.; Gruner, K.; Schuck, S.; Brautigam, A.; Zeier, J. Pipecolic Acid Orchestrates Plant Systemic Acquired Resistance and Defense Priming via Salicylic Acid-Dependent and -Independent Pathways. Plant Cell 2016, 28, 102-129. [CrossRef]

171. Navarova, H.; Bernsdorff, F.; Doring, A.C.; Zeier, J. Pipecolic acid, an endogenous mediator of defense amplification and priming, is a critical regulator of inducible plant immunity. Plant Cell 2012, 24, 5123-5141. [CrossRef]

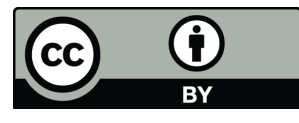

(C) 2020 by the authors. Licensee MDPI, Basel, Switzerland. This article is an open access article distributed under the terms and conditions of the Creative Commons Attribution (CC BY) license (http://creativecommons.org/licenses/by/4.0/). 